\title{
INTRAARTICULAR ALLOGENIC MESENCHYMAL STEM CELLS AND VASCULAR ENDOTHELIAL GROWTH FACTOR INJECTION IN ANTERIOR CRUCIATE LIGAMENT RECONSTRUCTION
}

\author{
Dwikora Novembri Utomo ${ }^{1,2}$, Ferdiansyah Mahyudin ${ }^{1,2}$, Arif Zulkarnain ${ }^{1}$, Purwati ${ }^{2}$, Rossy Setyawati ${ }^{3}$ \\ ${ }^{1}$ Department of Orthopedics \& Traumatology, ${ }^{2}$ Stem Cell Research and Development Centre, ${ }^{3}$ Department of \\ Radiology, Dr. Soetomo General Hospital/Universitas Airlangga, Surabaya, Indonesia
}

\section{ABSTRACT}

Graft tunnel healing is important for the successful reconstruction of the anterior cruciate ligament by using the hamstring tendon autograft. There are studies that intra graft tunnel Bone Marrow Mesenchymal stem cells (BMSCs) or intra graft tunnel Vascular endothelial growth factor (VEGF) accelerated graft tunnel healing. This study aimed to investigate the effect of using $B M S C s+V E G F$ injected intra-articular on graft tunnel healing. We reconstructed the anterior cruciate ligament (ACL) of 12 rabbits using an autograft hamstring tendon with and without intra-articular BMSCS+VEGF. Histological evaluation was done at 3 and 6 weeks after ACL reconstruction. On the surface between the graft and the bone tunnel obtained collagen fiber thickness or Sharpey fiber is significantly more than the control group $(p<0.05)$ in the evaluation of 3 weeks and 6 weeks either side of the tibia and the femur. To evaluate the progression of the treatment, treatment group and control group gained progression had significantly when compared to 3 weeks and 6 weeks. It can be concluded that intra-articular injection of $V E G F+B M S C$ s can accelerate the integration of the graft tunnel from histology evaluation on 3 and 6 weeks.

Keywords: Bone marrow mesenchymal stem cells; graft tunnel healing; anterior cruciate ligament reconstruction; sharpey fiber

\section{ABSTRAK}

Penyembuhan graft tunnel sangat penting pada rekonstruksi anterior cruciate ligament dengan menggunakan autograft hamstring tendon. Telah ada penelitian sebelumnya tentang implementasi Bone Marrow Mesenchymal Cells (BMSCs) yang diberikan pada intragraft tunnel dan telah terbukti mempercepat penyembuhan graft tunnel. Pada penelitian ini bertujuan untuk mencari efek dari implemantasi BMSCs ditambah VEGF yang diinjeksikan intra-artikular pada penyembuhan graft tunnel. Pada penelitian ini dilakukan rekonstruksi anterior cruciate ligament (ACL) pada 12 kelinci menggunakan autograft tendon hamstring yang dipisahkan menjadi diberi dan tidak diberi injeksi intra-artikular BMSCs ditambah VEGF selanjutnya dilakukan evaluasi histologis setelah 3 dan 6 minggu setelah rekonstruksi ACL. Pada permukaan antar graft dan terowongan tulang didapatkan ketebalan fiber kolagen atau sharpey fiber secara signifikan lebih banyak daripada grup kontrol $(p<0,05)$ pada evaluasi 3 minggu dan 6 minggu baik di sisi tibia maupun sisi femur. Untuk evaluasi progresivitas secara signifikan bila dibandingkan antara 3 minggu dan 6 minggu. Dapat disimpulkan bahwa injeksi intraartikular BMSCs ditambah VEGF dapat mempercepat integrasi graft tunnel pada pemeriksaan histologi minggu ke 3 dan ke 6.

Kata kunci: Bone marrow mesenchymal stem cells; penyembuhan graft tunnel; rekonstruksi anterior cruciate ligament; sharpey fiber

Correspondence: Dwikora Novembri Utomo; Jl. Manyar Tirtosari IV/7, Surabaya, Indonesia.

Phones: +628123036236; (031) 5020406. E-mail: dwikora_utomo@yahoo.com

pISSN:2355-8393 • eISSN: 2599-056x • doi: 10.20473/fmi.v56i1.18450

- Fol Med Indones. 2020;56:41-48 • Received 4 Jul 2018 • Accepted 17 Jan 2019

- Open access under CC-BY-NC-SA license • Available at https://e-journal.unair.ac.id/FMI/

\section{INTRODUCTION}

The incidence of knee injury in sport is very high. One of the most common knee injuries is the rupture of anterior cruciate ligament (ACL) which takes $50 \%$ of the pathology of knee injury (Baxter et al 2010). The incidence of ACL injuries based on the Australian
Football League (AFL) injury report in 2011 season was 0.9 new injuries per team per season and this injury causes football players miss their 13.4 games per team per season. In the UK, there are 100,000 patients with ACL rupture every year, while in the US there are 200,000 patients who require ACL reconstruction surgery every year (Smith et al 1993). 
ACL rupture in highly active patients who refuse to perform ACL reconstruction surgery will cause knee instability, meniscus and cartilage damage, early joint degenerative disease, and decreased of function in daily activity (Fithian et al 2002). In athletes, ACL rupture is the cause of the athleteâ $€^{\mathrm{TM}_{\mathrm{S}}}$ absence due to knee instability. In professional football players affected by ACL injury, reconstruction operation is mostly performed with goal to return to play as quickly as possible (Seijas et al 2013). An injured athlete costs estimatedly 20,000 US dollars for rehabilitation and can only return to play in six months (Smith et al 1993).

Many factors determine the success of ACL reconstruction surgery including fixation of the graft point, graft tension, graft material selection, and one of the most important is the healing of the graft tunnel. Graft tunnel is the weakest place in the early healing phase, this can lead to elongation phase to return to play. Therefore, stimulation is necessary to speed up the healing process of the graft tunnel so that it can be rehabilitated early and more aggressively to accelerate the return of the athletes.

It is generally known that the healing phase of grafttunnel is slower than the healing phase of bone. The first healing phase of graft-tunnel is the formation of fibrovascular tissue followed by bone growth into the soft tissues. This was followed by the growth of collagen fibers which connects tendon and bone, causing an indirect relationship between tendon and bone. The healing phase of graft-tunnel does not always occur normally in every patient after ACL reconstruction surgery whereby abnormal tissue growth at the graft tunnel may occur which lead to an increase in the movement of the knee or laxity (Benjamin et al 2007). Many studies show various modalities to improve the healing of graft-tunnel such as additional periosteum, bone morphogenetic protein, calcium phosphate cement, granulocyte colony-stimulating factor, transfer genes, and more.

Stem cell technology has grown rapidly over the last decade. Stem cells can differentiate into various tissues. One type of stem cells is mesenchymal stem cells (MSCs), which has been widely studied to enhance the healing of damaged tissues such as bone, cartilage tissue, fat tissue, tendons and muscle tissues. Therefore, it is expected MSCs can accelerate bone regeneration and fibrocartilage tissues under specific environmental conditions at the site of graft-tunnel (Kuang et al 2009).

Angiogenesis also plays an important role in bone growth, fracture healing, and soft tissue healing. This vascularization is responsible to deliver nutrients and precursor cells for growth and remodeling of damaged tissue. Vascular Endothelial Growth Factor (VEGF) is the key to the occurrence of angiogenesis. It is hypothesized that the addition of VEGF can accelerate the healing of graft tunnel.

Previous studies conducted using stem cells and vascular endothelial growth factor as an additional stimulus to accelerate the healing of graft-tunnel have shown good result. The study used fibrin-glue to hold the stem cells and was given intra-tunnel (Ouyang et al 2004, Yoshikawa et al 2006). It was a difficult implementation procedure and the cost of fibrin glue was very expensive. Synovial fluid containing collagenase and stromelysin substances proved to inhibit the acceleration graft-tunnel healing (Demirag et al 2006). The use of stem cells and VEGF injected intraarticular immediately after ACL reconstruction have never been studied. Intra-articular application can simplify the procedure and also save cost. Whether it can speed up the healing of graft-tunnel is still questionable.

In this study, we used allogenic bone marrow mesenchymal stem cells (BMSCs) and VEGF which were injected intra-articular immediately after ACL reconstruction. The study was invivo experiment using animal models.

\section{MATERIALS AND METHODS}

This is an experimental study with post-test-only control group design. The object of this study is New Zealand white rabbit with inclusion criterias of: male, 6-9 month-old, healthy (no defects), active, and body weight of $2000 \mathrm{~g} \mathrm{~A} \pm 500 \mathrm{~g}$. Twelve rabbits were divided into four groups. The first and the second group were control group whereby no stem cell nor VEGF was given. These two control groups were observed in different time after three and six weeks respectively. The third and the fourth group were the study group in which BMSCs and VEGF were injected intra-articularly and were observed at two different time of three and six weeks respectively. In this study, we compared the differences of sharpey fiber thickness in tibia and femur graft tunnel.

Data were grouped, analyzed and statistically tested. Data homogeneity was examined using Levene test. ANOVA test was performed to compare different groups. 


\section{RESULTS}

\section{Histology examination}

The histology of sharpey fiber thickness in tibia and femur graft tunnel between rabbits given the intraarticular injection of BMSCs+VEGF and control at 3 weeks and 6 weeks are shown in Table 1.

\section{Statistical analysis}

ANOVA statistical analysis as shown in Table 3 obtained the significant difference between 3 weeks control group and 3 weeks treatment group with significance value at $0.001(\mathrm{p}<0.05)$.

In Table 4, the significance value of 3 weeks tibia sidecontrol group and 3 weeks tibia side-treatment group is $0.001(p<0.05)$. While the significance value of 3 weeks femur side-control group and 3 weeks femur sidetreatment group is $0.002(\mathrm{p}<0.05)$.

ANOVA statistical analysis as shown in Table 5 obtained the significant difference between 6 weeks control group and 6 weeks treatment group with significance value at $0.001(\mathrm{p}<0.05)$. In Table 6 , the significance value between 6 of tibia side-control group and 6 weeks tibia side-treatment group is 0.001 $(\mathrm{p}<0.05)$. While the significance value of 6 weeks femur side-control group and 6 weeks femur side-treatment group is $0.002(\mathrm{p}<0.05)$.

ANOVA statistical analysis as shown in Table 7 obtained the significant difference between 3 weeks control group and 6 weeks control group with significance value at $0.014(\mathrm{p}<0.05)$. In Table 8 , the significance value of 3 weeks tibia side-control group and 6 weeks tibia side-control group is $0.027(\mathrm{p}<0.05)$. While the significance value of 3 weeks femur sidecontrol group and 6 weeks femur side-control group is $0.012(\mathrm{p}<0.05)$.

ANOVA statistical analysis as shown in Table 9 obtained the significant difference between 3 weeks treatment group and 6 weeks treatment group with significance value at $0.035(\mathrm{p}<0.05)$. In Table 10 , the significance value of 3 weeks tibia side-treatment group and 6 weeks tibia side-treatment group is 0.034 $(p<0.05)$. While the significance value of 3 weeks femur side-treatment group and 6 weeks femur side-treatment group is $0.032(\mathrm{p}<0.05)$.

\section{Hypothesis testing}

There is an effect of the additional of allogenic bone marrow mesenchymal stem cells (BMSCs) plus Vascular Endothelial Growth Factor (VEGF) intraarticularly to accelerated the healing of graft-tunnel after ACL reconstruction.

Based on Table 3, there was a significant statistical difference between 3 weeks control group and 3 weeks treatment group, while Table 7 showed the significant statistical difference between 3 weeks control group and 6 weeks control group. This is supported by Ouyang et al's (2004) study where fibrocartilage formation in the healing process of graft-tunnel is higher in the treatment group than the control group.

Based on Table 7, there was a significant statistical difference between 3 weeks control group and 6 weeks control group, while Table 9 showed the significant statistical difference between 3 weeks treatment group and 6 weeks treatment group. It was reported by Shen's (2010) study that tendon and bone insertion on graft tunnel indirectly or through sharpey fiber in the experimental animal are 6-24 weeks.

\section{DISCUSSION}

This study aims to explain the effect of intra-articular injection of BMSCs+VEGF on rabbit's knee after ACL reconstruction. The results of this study show that intraarticular injection of BMSCs+VEGF have potential to accelerate the healing of graft-tunnel as seen from the histology examination where formation collagen fiber or sharpey fiber is thicker at 3 weeks and 6 weeks both in tibia and femur.

Previously, there have been several studies on the healing of graft tunnel in animals after ACL reconstruction. Rodeo et al (2006) conducted an oblique extensor digitorum implantation on the rat proximal tibia. In that study, the use of autograft tendon hamstring implantation in femur and tibia intraarticularly produced similarities with ACL reconstruction. It is expected the graft tunnel environment resembled the conditions as in ACL reconstruction (Rodeo et al 2006).

Stem cells derived from bone marrow have been used to speed up the healing of graft tunnel. Ouyang et al (2004) in their study reported that bone marrow stromal cells can accelerate the healing of graft tunnel in rabbit. The histological examination showed perpendicular collagen fibers and tissue, such as cartilage in grafttunnel (Yoshikawa et al 2006). 
Table 1. Histology of sharpey fiber thickness

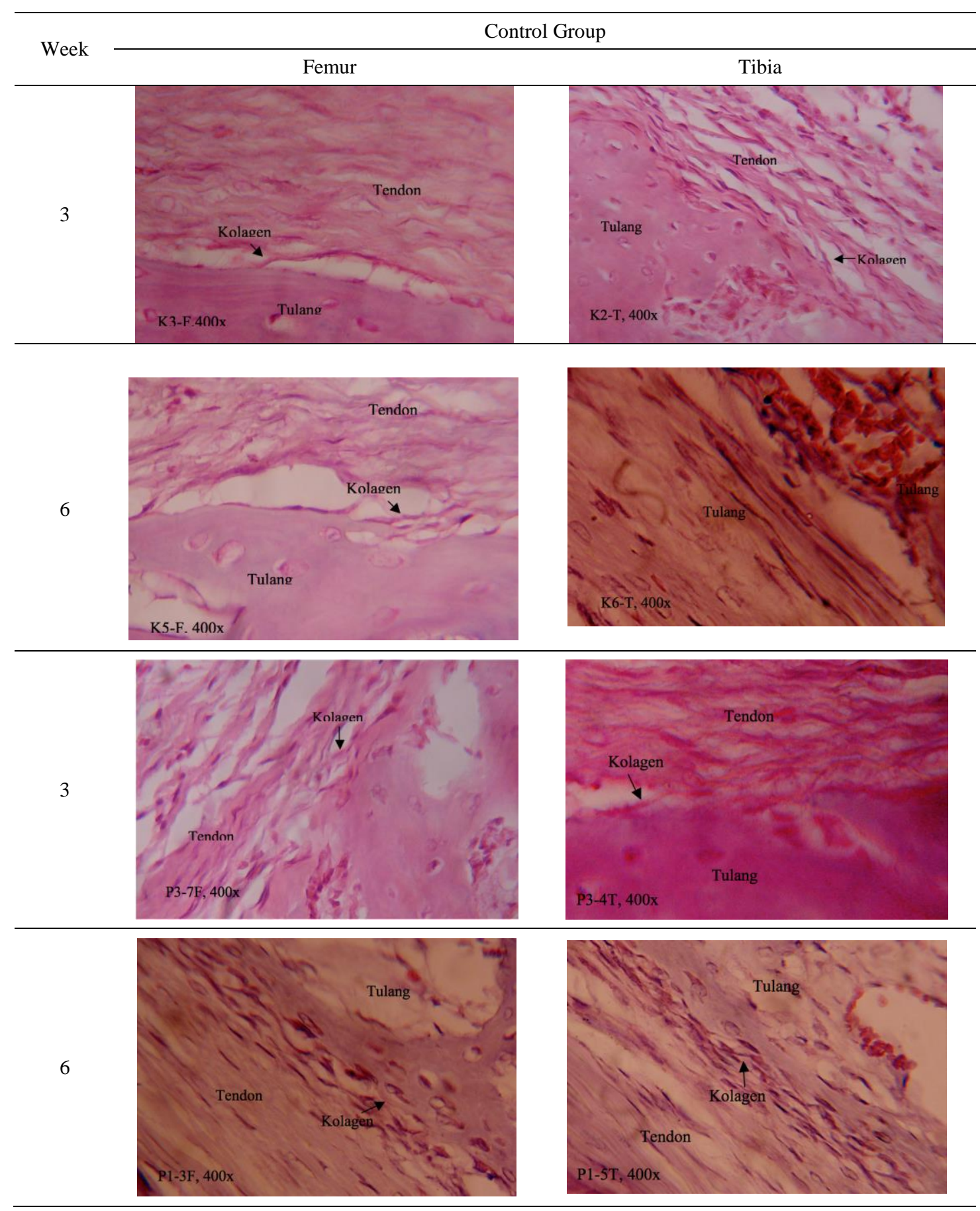

Table 2. Data normality test

\begin{tabular}{lcccccc}
\hline \multirow{2}{*}{ Groups } & \multicolumn{3}{c}{ Kolmogorov-Smirnov $^{\mathrm{a}}$} & \multicolumn{3}{c}{ Shapiro-Wilk } \\
\cline { 2 - 7 } & Statistic & $\mathrm{df}$ & Sig. & Statistic & df & Sig. \\
\hline Tibia 3 weeks & .143 & 12 & $.200^{*}$ & .926 & 12 & .335 \\
Femur 3 weeks & .180 & 12 & $.200^{*}$ & .944 & 12 & .552 \\
Tibia 6 weeks & .167 & 12 & $.200^{*}$ & .905 & 12 & .187 \\
Femur 6 weeks & .163 & 12 & $.200^{*}$ & .917 & 12 & .258 \\
\hline
\end{tabular}


Table 3. ANOVA statistical analysis at 3 weeks control group and 3 weeks treatment group

\begin{tabular}{lclccc}
\hline \multicolumn{1}{c}{ 3 Weeks } & Sum of Squares & df & Mean Square & F & Sig. \\
\hline Between Groups & 48.474 & 3 & 16.158 & & \\
Within Groups & 35.701 & 20 & 1.785 & 9.052 & .001 \\
Total & 84.174 & 23 & & & \\
\hline
\end{tabular}

Table 4. Multiple comparisons at 3 weeks control and treatment group in tibia and femur

\begin{tabular}{|c|c|c|c|c|c|c|}
\hline \multirow[b]{2}{*}{ (I) Groups } & \multirow[b]{2}{*}{ (J) Groups } & \multirow{2}{*}{$\begin{array}{l}\text { Mean } \\
\text { Difference } \\
(\mathrm{I}-\mathrm{J})\end{array}$} & \multirow[b]{2}{*}{ Std. Error } & \multirow[b]{2}{*}{ Sig. } & \multicolumn{2}{|c|}{ 95\% Confidence Interval } \\
\hline & & & & & Lower Bound & Upper Bound \\
\hline \multirow{3}{*}{$\begin{array}{l}3 \text { weeks tibia- } \\
\text { control }\end{array}$} & Femur-control & -.10000 & .77137 & .898 & -1.7090 & 1.5090 \\
\hline & Tibia-treatment & $-.93333^{*}$ & .77137 & .001 & -4.5424 & $-1.3243^{*}$ \\
\hline & Femur-treatment & $-.84833^{*}$ & .77137 & .001 & -4.4574 & $-1.2393^{*}$ \\
\hline \multirow{3}{*}{$\begin{array}{l}3 \text { weeks femur- } \\
\text { control }\end{array}$} & Tibia-control & .10000 & .77137 & .898 & -1.5090 & 1.7090 \\
\hline & Tibia-treatment & $-.83333^{*}$ & .77137 & .002 & -4.4424 & $-1.2243^{*}$ \\
\hline & Femur-treatment & $-.74833^{*}$ & .77137 & .002 & -4.3574 & $-1.1393^{*}$ \\
\hline \multirow{3}{*}{$\begin{array}{l}3 \text { weeks tibia- } \\
\text { treatment }\end{array}$} & Tibia-control & $2.93333^{*}$ & .77137 & .001 & 1.3243 & $4.5424^{*}$ \\
\hline & Femur-control & $2.83333^{*}$ & .77137 & .002 & 1.2243 & $4.4424^{*}$ \\
\hline & Femur-treatment & .08500 & .77137 & .913 & -1.5240 & 1.6940 \\
\hline \multirow{3}{*}{$\begin{array}{l}3 \text { weeks femur- } \\
\text { treatment }\end{array}$} & Tibia-control & $2.8483^{*}$ & .77137 & .001 & .2393 & $4.4574^{*}$ \\
\hline & Femur-control & $2.74833^{*}$ & .77137 & .002 & 1.1393 & $4.3574^{*}$ \\
\hline & Tibia-treatment & -.08500 & .77137 & .913 & -1.6940 & 1.5240 \\
\hline
\end{tabular}

Note: *: The mean difference is significant at the 0.05 level

Table 5. ANOVA statistical analysis at 6 weeks control group and 6 weeks treatment group

\begin{tabular}{lccccc}
\hline \multicolumn{1}{c}{ 3 Weeks } & Sum of Squares & df & Mean Square & F & Sig. \\
\hline Between Groups & 72.847 & 3 & 24.282 & & \\
Within Groups & 53.215 & 20 & 2.661 & 9.126 & .001 \\
Total & 126.062 & 23 & & & \\
\hline
\end{tabular}

Table 6. Multiple comparisons at 6 weeks control and treatment group in tibia and femur

\begin{tabular}{|c|c|c|c|c|c|c|}
\hline \multirow[b]{2}{*}{ (I) Groups } & \multirow[b]{2}{*}{ (J) Groups } & \multirow{2}{*}{$\begin{array}{c}\text { Mean } \\
\text { Difference } \\
(\mathrm{I}-\mathrm{J})\end{array}$} & \multirow[b]{2}{*}{ Std. Error } & \multirow[b]{2}{*}{ Sig. } & \multicolumn{2}{|c|}{ 95\% Confidence Interval } \\
\hline & & & & & Lower Bound & Upper Bound \\
\hline \multirow{3}{*}{$\begin{array}{l}6 \text { weeks tibia- } \\
\text { control }\end{array}$} & Femur-control & -.35833 & .94176 & .708 & -2.3228 & 1.6061 \\
\hline & Tibia-treatment & $-3.68000^{*}$ & .94176 & .001 & -5.6445 & $-1.7155^{*}$ \\
\hline & Femur-treatment & $-3.62833^{*}$ & .94176 & .001 & -5.5928 & $-1.6639^{*}$ \\
\hline \multirow{3}{*}{$\begin{array}{l}6 \text { weeks femur- } \\
\text { control }\end{array}$} & Tibia-control & .35833 & .94176 & .708 & -1.6061 & 2.3228 \\
\hline & Tibia-treatment & $-3.32167^{*}$ & .94176 & .002 & -5.2861 & $-1.3572^{*}$ \\
\hline & Femur-treatment & $-3.27000^{*}$ & .94176 & .002 & -5.2345 & $-1.3055^{*}$ \\
\hline \multirow{3}{*}{$\begin{array}{l}6 \text { weeks tibia- } \\
\text { treatment }\end{array}$} & Tibia-control & $3.68000^{*}$ & .94176 & .001 & 1.7155 & $5.6445^{*}$ \\
\hline & Femur-control & $3.32167^{*}$ & .94176 & .002 & 1.3572 & $5.2861^{*}$ \\
\hline & Femur-treatment & .05167 & & .957 & -1.9128 & 2.0161 \\
\hline \multirow{3}{*}{$\begin{array}{l}6 \text { weeks femur- } \\
\text { treatment }\end{array}$} & Tibia-control & $3.62833^{*}$ & .94176 & .001 & 1.6639 & $5.5928^{*}$ \\
\hline & Femur-control & $3.27000^{*}$ & .94176 & .002 & 1.3055 & $5.2345^{*}$ \\
\hline & Tibia-treatment & -.05167 & .94176 & .957 & -2.0161 & 1.9128 \\
\hline
\end{tabular}


Table 7. ANOVA statistical analysis at 3 weeks control group and 6 weeks control group

\begin{tabular}{lclccc}
\hline \multicolumn{1}{c}{ 3 Weeks } & Sum of Squares & df & Mean Square & F & Sig. \\
\hline Between Groups & 17.840 & 3 & 5.947 & & \\
Within Groups & 26.279 & 20 & 1.314 & 4.526 & .014 \\
Total & 44.119 & 23 & & & \\
\hline
\end{tabular}

Table 8. Multiple comparisons at 3 weeks and 6 weeks control group in tibia and femur

\begin{tabular}{|c|c|c|c|c|c|c|}
\hline \multirow[b]{2}{*}{ (I) Groups } & \multirow[b]{2}{*}{ (J) Groups } & \multirow{2}{*}{$\begin{array}{c}\text { Mean } \\
\text { Difference } \\
(\mathrm{I}-\mathrm{J})\end{array}$} & \multirow[b]{2}{*}{ Std. Error } & \multirow[b]{2}{*}{ Sig. } & \multicolumn{2}{|c|}{ 95\% Confidence Interval } \\
\hline & & & & & Lower Bound & Upper Bound \\
\hline \multirow{3}{*}{$\begin{array}{l}3 \text { weeks tibia- } \\
\text { control }\end{array}$} & 3 weeks femur-control & -.10000 & .66180 & .881 & -1.4805 & 1.2805 \\
\hline & 6 weeks tibia-control & $-1.57500^{*}$ & .66180 & .027 & -2.9555 & -.1945 \\
\hline & 6 weeks femur-control & $-1.93333^{*}$ & .66180 & .008 & -3.3138 & -.5528 \\
\hline \multirow{3}{*}{$\begin{array}{l}3 \text { weeks femur- } \\
\text { control }\end{array}$} & 3 weeks tibia-control & .10000 & .66180 & .881 & -1.2805 & 1.4805 \\
\hline & 6 weeks tibia-control & $-1.47500^{*}$ & .66180 & .037 & -2.8555 & -.0945 \\
\hline & 6 weeks femur-control & $-1.83333^{*}$ & .66180 & .012 & -3.2138 & -.4528 \\
\hline \multirow{3}{*}{$\begin{array}{l}6 \text { weeks tibia- } \\
\text { control }\end{array}$} & 3 weeks tibia-control & $1.57500^{*}$ & .66180 & .027 & .1945 & 2.9555 \\
\hline & 3 weeks femur-control & $1.47500^{*}$ & .66180 & .037 & .0945 & 2.8555 \\
\hline & 6 weeks femur-control & -.35833 & .66180 & .594 & -1.7388 & 1.0222 \\
\hline \multirow{3}{*}{$\begin{array}{l}6 \text { weeks femur- } \\
\text { control }\end{array}$} & 3 weeks tibia-control & $1.93333^{*}$ & .66180 & .008 & .5528 & 3.3138 \\
\hline & 3 weeks femur-control & $1.83333^{*}$ & .66180 & .012 & .4528 & 3.2138 \\
\hline & 6 weeks tibia-control & .35833 & .66180 & .594 & -1.0222 & 1.7388 \\
\hline
\end{tabular}

Table 9. ANOVA statistical analysis at 3 weeks treatment group and 6 weeks treatment group

\begin{tabular}{lclccc}
\hline \multicolumn{1}{c}{ 3 Weeks } & Sum of Squares & df & Mean Square & F & Sig. \\
\hline Between Groups & 32.837 & 3 & 10.946 & & \\
Within Groups & 62.637 & 20 & 3.132 & 3.495 & .035 \\
Total & 95.473 & 23 & & & \\
\hline
\end{tabular}

Table 10. Multiple comparisons at 3 weeks and 6 weeks treatment group in tibia and femur

\begin{tabular}{|c|c|c|c|c|c|c|}
\hline \multirow[b]{2}{*}{ (I) Groups } & \multirow[b]{2}{*}{ (J) Groups } & \multirow{2}{*}{$\begin{array}{c}\text { Mean } \\
\text { Difference } \\
(\mathrm{I}-\mathrm{J})\end{array}$} & \multirow[b]{2}{*}{ Std. Error } & \multirow[b]{2}{*}{ Sig. } & \multicolumn{2}{|c|}{ 95\% Confidence Interval } \\
\hline & & & & & Lower Bound & Upper Bound \\
\hline 3 weeks & 3 weeks femur-treatment & .08500 & 1.02174 & .935 & -2.0463 & 2.2163 \\
\hline tibia- & 6 weeks tibia-treatment & $-2.32167^{*}$ & 1.02174 & .034 & -4.4530 & $-.1904^{*}$ \\
\hline treatment & 6 weeks femur-treatment & $-2.27000^{*}$ & 1.02174 & .038 & -4.4013 & $-.1387^{*}$ \\
\hline 3 weeks & 3 weeks tibia-treatment & -.08500 & 1.02174 & .935 & -2.2163 & 2.0463 \\
\hline femur- & 6 weeks tibia-treatment & $-2.40667^{*}$ & 1.02174 & .029 & -4.5380 & $-.2754^{*}$ \\
\hline treatment & 6 weeks femur-treatment & $-2.35500^{*}$ & 1.02174 & .032 & -4.4863 & $-.2237^{*}$ \\
\hline 6 weeks & 3 weeks tibia-treatment & $2.32167^{*}$ & 1.02174 & .034 & .1904 & $4.4530^{*}$ \\
\hline tibia- & 3 weeks femur-treatment & $2.40667^{*}$ & 1.02174 & .029 & .2754 & $4.5380^{*}$ \\
\hline treatment & 6 weeks femur-treatment & .05167 & 1.02174 & .960 & -2.0796 & 2.1830 \\
\hline 6 weeks & 3 weeks tibia-treatment & $2.27000^{*}$ & 1.02174 & .038 & .1387 & $4.4013^{*}$ \\
\hline femur- & 3 weeks femur-treatment & $2.35500^{*}$ & 1.02174 & .032 & .2237 & $4.4863^{*}$ \\
\hline treatment & 6 weeks tibia-treatment & -.05167 & 1.02174 & .960 & -2.1830 & 2.0796 \\
\hline
\end{tabular}

Lim et al (2004) conducted a study using BMSCs with the results of the healing improvement through cartilage formation in graft tunnel. It also obtained a significantly better result in biomechanical than the control group (rabbit with ACL reconstruction using hamstring tendon). Yoshikawa et al (2006) conducted a study using VEGF as an additional biological material after ACL reconstruction in sheep. There was significantly more angiogenesis formation in graft tunnel in the treatment group than in the control group (Demirag et al 
2006). In this study, the additional biological materials used were BMSCs and VEGF injected intra-articularly. The difference with previous study is the content of the additional biological materials which was a combination of stem cells derived from bone marrow and growth factor. The previous study used collagen gel injected intra-tunnel while this study used intra-articular techniques. The advantages of intra-articular injection techniques are easier and less expensive for clinical applications.

In this study obtained a thicker sharpey fiber in the treatment group than control group at 3 weeks and 6 weeks significantly both on tibia and femur. This can be indicated that the addition of BMSCs+VEGF can accelerate the healing of graft tunnel, mainly acts as a stimulus for collagen maturation to become a sharpey fiber in the graft tunnel environment. Bone marrow mesenchymal stem cells (BMSCs) are nonhematopoietic stem cells of the adult stem cell population in the bone marrow that can differentiate into bone, cartilage, fat tissue, and connective tissue (Ratajczak et al 2007). The results of this study indicate that intra-articular injection of BMSCs can differentiate into fibroblasts in graft-tunnel environment to form sharpey fiber. This will accelerate the initial remodeling in graft-tunnel healing.

In comparison between 3 weeks control group and 6 weeks control group both tibia and femur was found significant difference. It also obtained significant difference between 3 weeks treatment group and 6 weeks treatment group in tibia and femur. This indicates that the healing process in graft tunnel still progress, and it does not stop at 3 weeks.

Some limitation of this study is that no biomechanical testing conducted to determine whether the addition of intra-articular injection of BMSCs+VEGF also accelerate the healing of graft tunnel. In a previous study reported that the maximum tensile force required by the tendon to escape from the tunnel is progressively increased in proportion to the growth of collagen or sharpey fiber (Rodeo et al 2006). Therefore, according to that study, it can be assumed that the results of this study can also increase the maximum tensile force of the tendon graft to escape from the tunnel.

Furthermore, this study can not distinguish whether the healing acceleration in graft tunnel because of BMSCs or because of VEGF, so labeling on VEGF can detect the role of VEGF on graft tunnel healing can be an idea for further research.

\section{CONCLUSION}

From this study we can conclude that intra-articular injection of VEGF+BMSCs can accelerate the integration of the graft-tunnel from histology evaluation on 3 and 6 weeks.

\section{REFERENCES}

Baxter FR, Bach JS, Detrez F (2010). Augmentation of bone tunnel healing in anterior cruciate ligament graft: application of calcium phosphates and other materials. Journal of Tissue Engineering, 1-12. Available at https://www.ncbi.nlm.nih.gov/pmc/articles/PMC3042 684/

Benjamin C, et al (2007). Bone morphogenetic proteins -signaling plays a role in tendon-to-bone healing. The American Journal Of Sport Medicine 35, 597-605. Available at http://journals.sagepub.com/doi/abs/10. $1177 / 0363546506296312$

Demirag B, Sarisozen B, Ozer O, Kaplan T, Ozturk C (2006). Enhancement of Tendon-Bone Healing of Anterior Cruciate Ligament Grafts by Blockage of Matrix Metalloproteinases. J Bone Joint Surg Am 87, 2401-2410. Available at https://www.ncbi.nlm.nih. gov/pubmed/16264114

Fithian DC, Paxton LW, D. Goltz (2002). Fate of the anterior cruciate ligament-injured knee. Orthop Clin North Am 4, 621-36. Available at https:// www.ncbi.nlm.nih.gov/pubmed/12528905

Kuang GM, et al (2009). Osteointegration of soft tissue grafts within the bone tunnels in anterior cruciate ligament reconstruction can be enhanced. Knee Surg Sport Traumatol Arthrosc 18, 1038-1051

Lim JK, Hui J, and L. Li (2004). Enhancement of tendon graft osteointegration using mesenchymal stem cells in a rabbit model of anterior cruciate ligament reconstruction. Arthroscopy 20, 899-910. Available at https://www.ncbi.nlm.nih.gov/pubmed/15525922

Ouyang HW, Goh James CH, Eng HL (2004). Use of bone marrow stromal cells for tendon graft-to-bone healing. The American Journal of Sports Medicine 32, 321-327. Available at http://journals.sagepub.com/doi/ abs/10.1177/0095399703258682

Ratajczak MZ, Machalinski BW, Wojakowski (2007). A hypothesis for an embryonic origin of pluripotent Oct-4+ stem cells in adult bone marrow and other tissue. Leukimia 21, 860-7. Available at https:// www.nature.com/articles/2404630

Rodeo SA, Kawamura S, Kim H (2006). Tendon healing in a bone tunnel differs at the tunnel entrance versus the tunnel exit: an effect of graft tunnel motion? American Journal of Sports Medicine 34, 1790-1800. Available at http://journals.sagepub.com/ doi/abs/10.1177/0363546506290059 
Seijas R, Rius M, Ares O, Garcia-Balletbo M, Serra I, Cugat R (2015). Healing of donor site in bone-tendonbone acl reconstruction accelerated with plasma rich in growth factors: a randomized clinical trial. Knee Surg Sport Traumatol Arthrosc 23, 991-7

Shen H, Qiao G, Cao H and Yao J (2010). An histological study of the influence of osteoinductive, calcium phosphate ceramics on tendon healing pattern in a bone tunnel with suspensory fixation. International Orthopaedics (SICOT) 34, 917-924
Yoshikawa T, et al (2006). Effects of local administration of vascular endothelial growth factor on mechanical characteristics of the semitendinosus tendon graft after anterior cruciate ligament reconstruction in sheep. The American Journal of Sports Medicine 34, 1918-1924. Available at http://journals.sagepub.com/doi/abs/10.1177/0363546 506294469 